\title{
電界解析による水トリー進展特性検討
}

\author{
正 員 中出 雅彦* 正 員 井上 大輔*
}

\section{A Study of Characteristics of Water Tree Growth by Electric Field Analysis}

\author{
Masahiko Nakade*, Member, Daisuke Inoue*, Member
}

\begin{abstract}
Three-dimensional electric fields analysis was applied to the tip of water trees in XLPE cable. First, pre-breakdown detection was curried out on "needle-shaped" water trees. The results were analyzed by the three-dimensional electric field F.E.M. The water tree was simplified by a spheroid in the analysis. The position of the trees, length, tip radius were read from the microphotographs. The analysis was done on all 11 examples. The test results could be explained well when the conductivity of the water tree region was assumed to be $5 \times 10^{-7} \mathrm{~S} / \mathrm{m}$. Next, the electric fields of tip of three kinds of water tree ("blue", "needleshaped" and "white" water tree) were analyzed. Three kinds of water tree were expressed by changing the conductivity of water tree region. And, a distance from water trees to inside half conductor was made to change in three kinds. These were analyzed about the cable (insulation thickness: $3,6,9 \mathrm{~mm}$ ) of $6.6,22$, $66 \mathrm{kV}$ respectively. It was found out that "blue" and needle-shaped tree in the $66 \mathrm{kV}$ cable and "blue" tree in the $22 \mathrm{kV}$ cable may cause a breakdown under the operation voltage. As for other cases, the tree may propagate without making breakdown until it bridges the insulation. And, the possibility that the growth of "white" water tree declined rapidly in 66 , the $22 \mathrm{kV}$ cable when it touches inner semi-conducting layer so that the tip electric fields of the tree are the same as the average electric fields of the cable was suggested.
\end{abstract}

キーワード:水トリー, 電界解析, CV ケーブル

Keywords: water tree, electric field analysis, XLPE cable

\section{1.はじめに}

これまで，何件もの氷トリーによる事故が発生しており， その原因については各種報告がなされている(1) (3)。その中

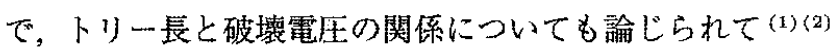
いるが，それぞれの水トリーについての報告であった。

そこで, 我々は 3 次元有限要素法による電界解析を前駆 遮断試験結果が豊富に存在する水トリ一について行い，水 トリー長, ·前駆遮断電圧の試験值と 3 次元有限要素法によ る先端電界解析值との比較を行い，水トリーの導電率につ いての考察を行った。この考察を受けて, 3 種類の代表的な 水卜リーについて絶縁厚, 水卜リ一長, 導電率の水トリ一 先端電界に及湆す影響を再度, 3 次元有限要素法で解析し, それぞれの水トリー進展の特徴について考察した。

\footnotetext{
* 東京電力 (株) 技術開発研究新

$\bar{\Upsilon}$ 230-8510 横浜市鹤見区江々㱦 4-1

R\&D Center, Tokyo Electric Power Co.

4-1, Egasaki-cho, Tsurumi-ku, Yokohama 230-8510
}

\section{2. 針状トリーの前駆遮断試験結果}

水トリーは架橋ポリエチレンケーブル（以下 CV ケーブ ル）の絶縁体に水と電界が加わった時に発生するが, これ 以外に特殊な要因が加わった時に特殊な形状の水卜リーが 発生することが知られている (1)(3)。その内の一つが針状水 トリーであり，通常の水トリーに比べ細長い形状をしてい る。針状水トリーは通常の水トリー発生要因（異物，水分， 電界）の他に絶縁体の柾为が影響しているとされている(3)。

$\langle 2 \cdot 1\rangle$ 試料, 試験方法 調查の対象としたケーブルは, $66 \mathrm{kVCV}$ ケーブル (絶縁厚 $11 \mathrm{~mm}$ ), $150 \mathrm{~mm}^{2}$ であり, 運 転中に絶縁破壊した線路からの撤去品である。E-Eタイプ (内部, 外部半導電層, 絶緑体同時押しだし), 乾式架橋で 製造され，管路布設状態で 23 年間使用されたものである。 絶䩮体押出工程において，若干架穚が准んた（プレ架橋）ポ リエチレン樹脂が押し出されていたため，絶縁体中に歪み が生じていると考えられる。破壊原因調查のため，多数の 試料に対し前駆遮断試験と破壊起点の観測を行った。前駆 遮断試験は周波数 $50 \mathrm{~Hz}$ ，開始電圧 $50 \mathrm{kV}, 10 \mathrm{kV} / 10$ 分の 昇圧により行い，部分放電発生位置を同定した㮃，同部位 
表 1 前駆遮断結果（電気トリー発生水トリー）

Table 1. AC pre-breakdown detection results

(Water trees with electrical tree).

\begin{tabular}{|c|c|c|c|c|c|c|c|}
\hline $\begin{array}{l}\text { 試料 } \\
\text { No. }\end{array}$ & $\begin{array}{l}\text { 遮断 } \\
\text { 電厓 } \\
{[\mathrm{kV}]}\end{array}$ & 形状 & $\begin{array}{c}\text { 水トリー } \\
\text { 位置·種類 }\end{array}$ & $\begin{array}{c}\text { 水トリ- } \\
\text { 長 } \\
{[\mu \mathrm{m}]}\end{array}$ & $\begin{array}{c}\text { 電気トリー } \\
\text { 発生点 }\end{array}$ & \begin{tabular}{|c} 
水トリー先端 \\
曲率 (電気卜 \\
リ一発生点) \\
{$[\mu \mathrm{m}]$}
\end{tabular} & $\begin{array}{c}\text { 内禎表面 } \\
\text { BTT下端の } \\
\text { 距離 } \\
{[\mu \mathrm{m}]}\end{array}$ \\
\hline (1) & 80 & 針状 & 内導近傍BTT & 1900 & BTT下端 & 17.5 & 100 \\
\hline (2) & 60 & 針状 & 内導接触 BTT & 2780 & BTT上端 & 20 & - \\
\hline (3) & 70 & 針状 & 内導近傍 BTT & 2480 & BTT下端 & 20.8 & 67 \\
\hline (4) & 70 & 針状 & 内導近傍 BTT & 3030 & BTT下端 & 20 & 280 \\
\hline (5) & 100 & 針状 & 内導近傍 BTT & 750 & BTT下端 & 9.6 & 60 \\
\hline (6) & 60 & 針状 & 内導近傍 BTT & 2720 & BTT下端 & 15.4 & 62 \\
\hline (7) & 110 & 針状 & 内導近傍 BTT & 1100 & BTT下端 & 不鮮明 & 不鮮明 \\
\hline (8) & 170 & 針状 & 内導近傍 BTT & 520 & BTT下端 & 20.8 & 50 \\
\hline (9) & 110 & 針状 & 内远トリー & 620 & 内導突起 & 16.7 & - \\
\hline (110) & 75 & 針状 & 内導近傍 BTT & 2470 & BTT下端 & 42.3 & 169 \\
\hline (11) & 160 & 針状 & 内導トリー & 300 & 内導突起 & 22.7 & - \\
\hline (12) & 80 & 針状 & 内導近傍 BTT & 1480 & BTT下端 & 19.2 & 230 \\
\hline (13) & 85 & 針状 & 内導接触 BTT & 2320 & BTT上端 & 12.5 & - \\
\hline (14) & 90 & 針状 & 内導近傍 BTT & 2320 & BTT下端 & 45.8 & 166 \\
\hline (15) & 70 & 針状 & 内導近傍BTT & 4900 & BTT上下端 & 43.8 & 100 \\
\hline (16) & 80 & 針状 & 内導近傍 BTT & 2400 & BTT下端 & 29.2 & 150 \\
\hline
\end{tabular}

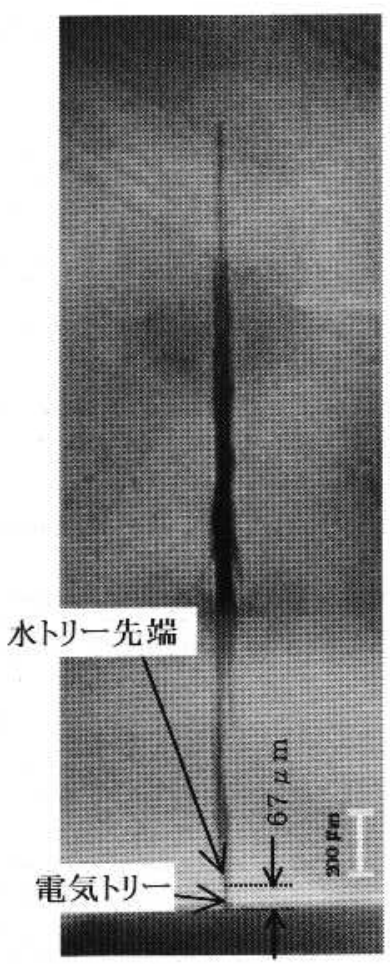

図 1 針状水トリー（試料 No.3）

Fig. 1. Needle-shaped water tree.
の絶縁体を $0.5 \mathrm{~mm}$ 厚にスライスし, 電気トリー発生起点 を光学顕微鏡で観测した。

$\langle 2 \cdot 2\rangle$ 結 果 前駆遮断電圧は $100 \mathrm{kV}$ 以下のもの が多く, $66 \mathrm{kV}$ ケーブルとしては残存性能が極めて低下して いる。破壊起点観測の結果, 16 試料に電気トリー発生が観 測され，電気トリー発生起点は全て水トリーであった。16 試料の水トリーを観察すると, 14 試料はボウタイトリー, 2 陚料は内導トリーであり, その形状は通常の水トリーより 細長く, 全て針状であった。またトリー先端曲率は $20 \mu \mathrm{m}$ 以下のものが多く, 非常に先の尖ったトリーであった。こ の結果から,プレ架橋の絶䋑体歪みに由来する水トリーが 進展すると, 針状になり, 先端曲率が小さいため有害度が 高くなると考えられる。ボウタイトリーの電気トリー発生 点を調查すると, 内部半導電層 (以下内導) 側のトリー先 端が電気トリーの発生点となっており, 内導と電気トリー 発生点までの距離は $50 \sim 280 \mu \mathrm{m}$ と, 内導に極めて接近し たボウタイトリーであった。これから内導近傍のボウタイ トリーの先端は高電界の状到にあることが予想される。

\section{3. 針状トリーの先端電界と導電率}

先の前駆遮断結果, 16 例のうち, 写真が不鮮明なもの, 内導異物を起点とした水トリー, および, 内導に接触した ものを除いた全 11 例について 3 次元の有限要素法による 電界解析を行った。

〈3・1〉 解析条件 有限要素法プログラムには株式会 社日本総合研究所 JMAG-Studio を使用した。図 1 に示 すように, 針状トリーは形状が 3 次元的にあまり複雑でな
く，比較的解析しやすい。まず，水トリー全体を回転棈円 体形状で近似した。回転楕円体の先端電界は平等電界中で は解析的に解けるが, 発散性電界中の電界方向に長い水卜 リー先端の内導側および外導側電界の違い等は, 有限要素 法で初めて定量的に論じることができる。このため, 3 次 元有限要素法を使用した。電界が集中する水トリー先端は $2 \mu \mathrm{m}$ 程度に細かくメッシュを切り, 写真から読みとった 先端曲率を再現した。針状トリーは異物を基点として発生 しているが, 簡単のため, 異物や異物周辺の形状の再現は 行わなかった。

試料 No.3 の例を図 2, 図 3 に示す。水トリー長手方向に 刘称軸をとり，1/4 領域の解析を行っている。またケープル は中心から 30 度の角度まで, ケーブル長手方向には $5 \mathrm{~mm}$ を解析対象とした。また, ケーブル内導に電位 $38.1 \mathrm{kV}$ を 与え, 外導に電位 $0 \mathrm{~V}$ をえた。

坂本ら (4)によると水トリーの先端電界を論じる場合には 導電率が重要であることを指摘している。針状トリーの比 誘電率は 10 ～ 80 である ${ }^{(2)}$ とするものがあり, 仮に複素誘 電率を 80 , 比誘電率 2.3 とすると, 下式で $\varepsilon \ll \sigma / \omega \varepsilon_{0}$ が ほほ成立し, 導電率は $2.2 \times 10^{-7} \mathrm{~S} / \mathrm{m}$ となる。

$$
\begin{aligned}
& \varepsilon^{*}=\varepsilon-j \sigma / \omega \varepsilon_{0} \\
& \left(\varepsilon^{*}: \text { 複素比誘電率, } \varepsilon: \text { 比誘電率, } \sigma:\right. \text { 導電率, } \\
& \left.\varepsilon_{0}: \text { 真空 } の \text { 誘電率 }\right)
\end{aligned}
$$

そこで, 水トリー部の導電率として $2.2 \times 10^{-7} \mathrm{~S} / \mathrm{m}$ と, 若 干大きな $5 \times 10^{-7} \mathrm{~S} / \mathrm{m}$ の 2 通りで計算を行った。ポリエチ レンの比誘電率は 2.3 , 導電率は $0 \mathrm{~S} / \mathrm{m}$ を与えた。実際の 


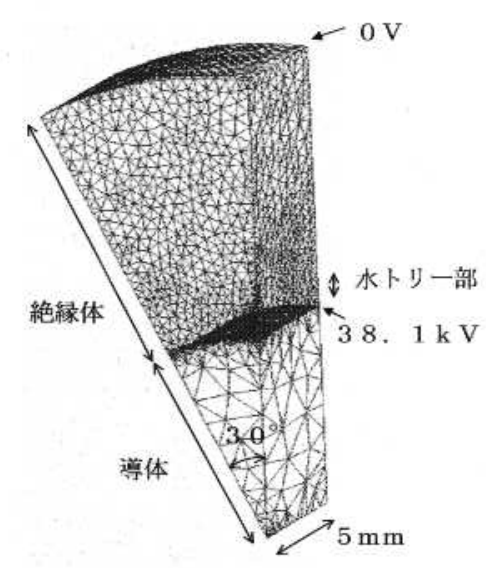

図 2 試料 No.3 のメッシュ全体図

Fig. 2. Whole mesh figure of sample No.3.

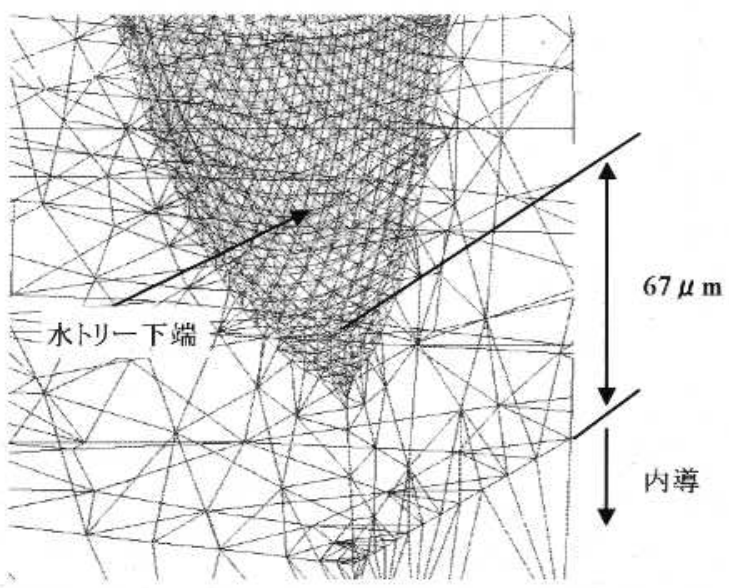

図 3 試料 No.3 の水トリー下端のメッシュ

Fig. 3. Bottom mesh figure of sample No.3 water tree.

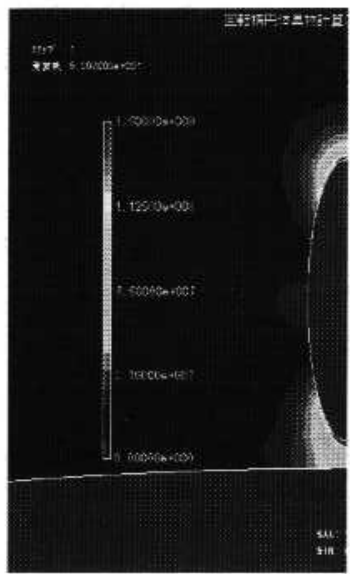

図 4 水トリー部の電界強度

Fig. 4. Electric field strength of a water tree.

ポリエチレンの導電率は $10^{-14} \mathrm{~S} / \mathrm{m}$ 程度であるが, 電界解 析上, 水トリー部の導電率が $10^{6}$ 以上大きいため, 0 と置 いて問題ない。ケーブル絶縁厚は $11 \mathrm{~mm}$ を与えた。

〈3.2〉 解析結果と考察 解析結果の一例を図 4 に示

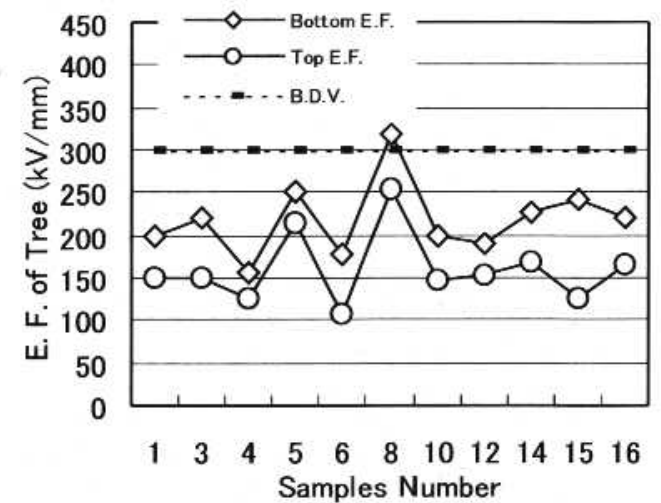

図 5 水トリー部先端電界 (導電率 $\left.2.2 \times 10^{-7} \mathrm{~S} / \mathrm{m}\right)$

Fig. 5. E. F. of water tree top $\left(\sigma=2.2 \times 10^{-7} \mathrm{~S} / \mathrm{m}\right)$.

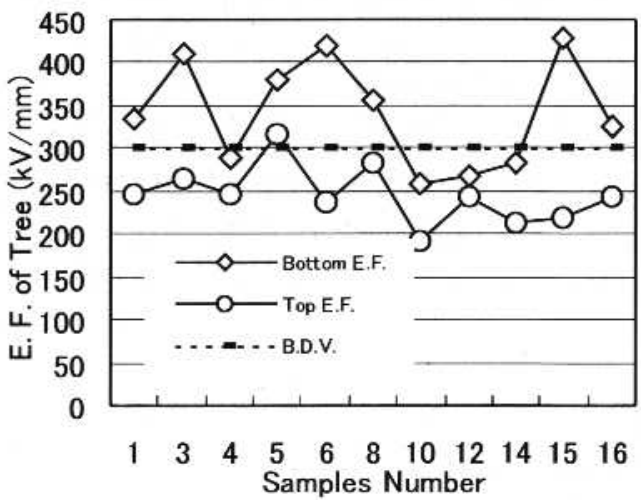

図 6 水トリー部先端電界 (導電率 $\left.5.0 \times 10^{-7} \mathrm{~S} / \mathrm{m}\right)$

Fig. 6. E. F. of water tree top $\left(\sigma=5.0 \times 10^{-7} \mathrm{~S} / \mathrm{m}\right)$.

す。図 5 , 図 6 に, 水トリー部の上端（外導侧）と，下端 (内導側) の電界を示す。先端電界は水トリー上端より下端 の方が大きく、これは，11 例全ケースについて水トリー下 端で破壊が起こっていることに対応している。また, 導電 率を $5.0 \times 10^{-7} \mathrm{~S} / \mathrm{m}$ とした場合，水トリー下端電界は架 橋ポリエチレンのトリー開始電界 ${ }^{(5)}(\mathrm{n}=15$ の時の, 15 分 值） $300 \mathrm{kV} / \mathrm{mm}$ を越え, 前駆遮断時の電界で十分破壊す る可能性があることが分かる。 $2.2 \times 10^{-7} \mathrm{~S} / \mathrm{m}$ では電界が $300 \mathrm{kV} / \mathrm{mm}$ まで達せず，もう少し高い電圧を印加する必 要があると思われる。したがって, 針状トリーの導電率は $5.0 \times 10^{-7} \mathrm{~S} / \mathrm{m}$ 程度が適当であると推定できる。

\section{4. 水トリーの先端電界検討}

$\langle\mathbf{4} \cdot \mathbf{1}\rangle$ 解析条件 水トリーの種類には発生する位置に よって, 内導トリー, ボウタイトリー, 外導トリーなどが ある。また，運転中に事故を引き起こしたトリーに関して は, 特に, 特殊内導トリー (青色トリー(1) $)$, 針状トリーと 言う区分けがある。青色トリー，針状トリーは誘電率が極 めて高いと考えられており，有害性が高い。これ以外の水 トリーは発生位置によらずそれほど有害性が高いと考えら 
表 2 卜リー種類と導電率, 比誘電率

Table 2. Conductivity and relative permittivity of water tree.

\begin{tabular}{|c|c|c|}
\hline トリ正種類 & 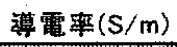 & 比誘電辈 \\
\hline 青色 & $2.8 \times 10^{-2}$ & 2.3 \\
\hline 針状 & $5.0 \times 10^{-7}$ & 2.3 \\
\hline 白色 & $1.5 \times 10^{-8}$ & 2.3 \\
\hline
\end{tabular}

表 3 対象ケーブル構造

Table 3. Cables construction.

\begin{tabular}{|c|c|c|c|c|c|}
\hline 電在 & 絶縁厲 & 溥体サイズ & 内邉半经 & 外道半径 & 対地電压 \\
\hline $66 \mathrm{kV}$ & $9 \mathrm{~mm}$ & $200 \mathrm{~mm} 2$ & $9.5 \mathrm{~mm}$ & $18.5 \mathrm{~mm}$ & $38.1 \mathrm{kV}$ \\
\hline $22 \mathrm{kV}$ & $6 \mathrm{~mm}$ & $200 \mathrm{~mm} 2$ & $9.5 \mathrm{~mm}$ & $15.5 \mathrm{~mm}$ & $12.7 \mathrm{kV}$ \\
\hline $6.6 \mathrm{kV}$ & $3 \mathrm{~mm}$ & $200 \mathrm{~mm} 2$ & $9.5 \mathrm{~mm}$ & $12.5 \mathrm{~mm}$ & $3.8 \mathrm{kV}$ \\
\hline
\end{tabular}

れておらず，顕微鏡写真で白色に見えることより，本論文 では白色トリー(1) と呼ぶ。

解析はボウタイトリーを中心に行い，内導に接触した場合 (case1), 内導から水トリー下端まで $50 \mu \mathrm{m}$ の場合 (case2), ボウタイトリー中心が絶緑体中心の場合 (case3) の 3 通り について行った。また，それぞれの位置で，青色卜リー，針 状トリー，白色トリ一の先端電界を解析した。青色トリー は内菹異物加発生するため，ボウタイトリーの解析では そのものを解析できないが, 内導に接触したボウタイトリー は実質内導トリーと同様な解析となるため，代用した。

青色卜リ一の複素誘電率については，大野らの論文 ${ }^{(1)}$ 加 ら $10^{7}$ が得られており，先ほどと同様に導䉓率を求めると $2.8 \times 10^{-2} \mathrm{~S} / \mathrm{m}$ となる。白色トリーに関しては，豊田ら の論文 ${ }^{(6)}$ より $50 \mathrm{~Hz}$ グ語つ読み值より, $1.5 \times 10^{-8} \mathrm{~S} / \mathrm{m}$,

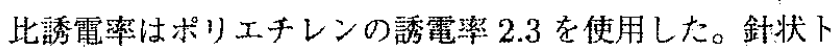
リ一に関しては前峃の結果により, 導電率 $5.0 \times 10^{-7} \mathrm{~S} / \mathrm{m}$, 比誘電率 2.3 を使用した。条件を表 2 にまとめる。

それぞれのケースを表 3 に示す 3 ケースのケーブルにつ いて解析を行った。また，氷卜リ一長は絶縁厚に対する割 合， $1 ， 3 ， 5 ， 7,9$ 割の長さで解析を行った。例之ば絶縁 厚 $9 \mathrm{~mm}$ の場合, 0.3 は $9 \mathrm{~mm} \times 0.3=2.7 \mathrm{~mm}$ となる。解 析は前章と同様に 3 次元有限要素法により解析を行い, 水 トリー先端電界のみを示す。

$\langle 4$-2〉解析結果图 7 図 15 に結果示示。図中 に電気卜リ一開始電界 $300 \mathrm{kV} / \mathrm{mm}$ と，ケーブル平均電界 Emean 記述した。結果を以下にまとめる。

・水卜リ一先端電界は, $66,22,6.6 \mathrm{kV}$, 拉よび, 青色, 針状，白色の順で高い（図 7 図 15 参照)。

-水卜リ一先端電界が電気卜リ一開始電界 $300 \mathrm{kV} / \mathrm{mm}$ を越えるのは， $66 \mathrm{kV}$ では，青色，針状，22kVでは 青色トリーのみである（図 7 図 9, 図 11 参照)。

- $66,22 \mathrm{kV}$ ケーブルでは，白色卜リ一の先端が内導に 接触すると, 承トリ一上端電界はケーブル平均電界程 度となる(図 7, 図 10 参照)。

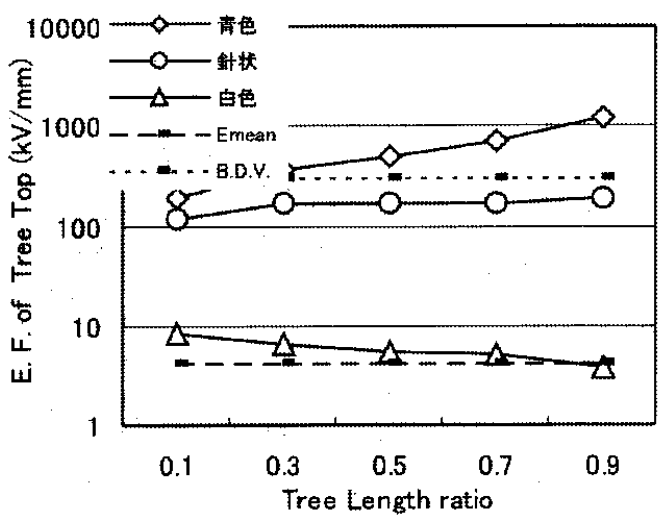

図 7 水卜リ一上端電界 $(66 \mathrm{kV}$ クラス, case 1$)$ Fig. 7. E: F. at the upper tip of the water tree (66 kV class, case1).

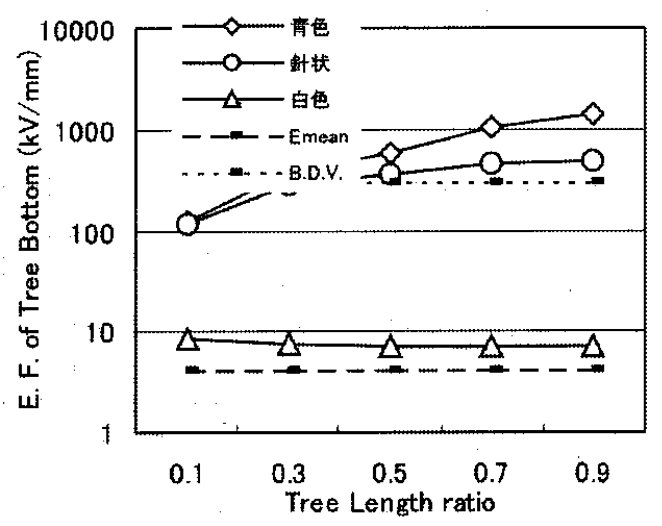

图 8 我トリ一下端電界 $(66 \mathrm{kV}$ クラス, case 2$)$ Fig. 8. E. F. at the lower tip of the water tree $(66 \mathrm{kV}$ class, case 2$)$.

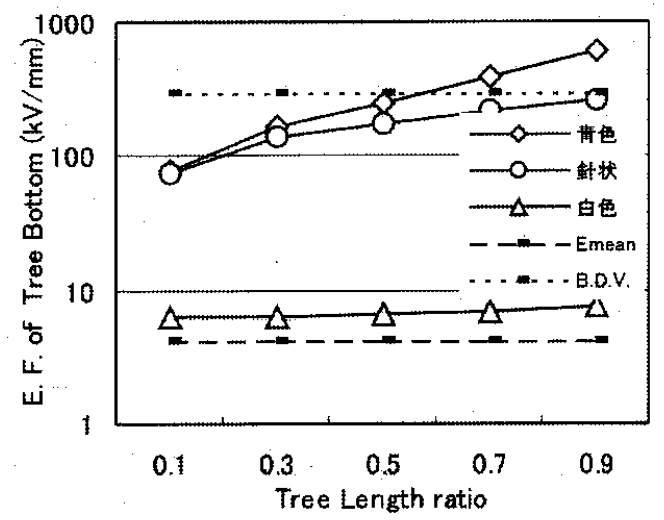

图 9 水トリ一下端電界 $(66 \mathrm{kV}$ クラス, case3) Fig. 9. E. F. at the lower tip of water tree $(66 \mathrm{kV}$ class, case3).

〈4・3〉考察 トリー種類ごとに 3 章の結果も合 わせ，結果から推測できることをとめる。 青色トリー

・水トリーの進展とともに電界が上暴し，水卜リ一は更 に進展すると考えられる。66 kV，22kV ケーブルで は，水卜リ一が貫通する前に先端電界が $300 \mathrm{kV} / \mathrm{mm}$ 


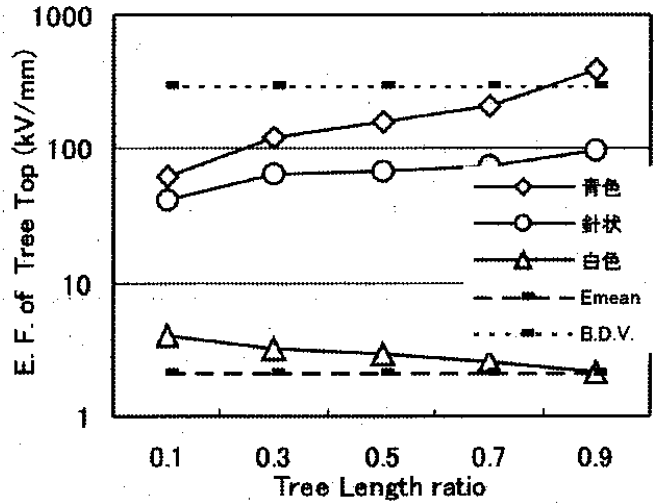

図 10 水トリ一上端電䱊 $(22 \mathrm{kV}$ クラス, case1) Fig. 10. E. F. at the upper tip of the water tree (22 kV class, case1).

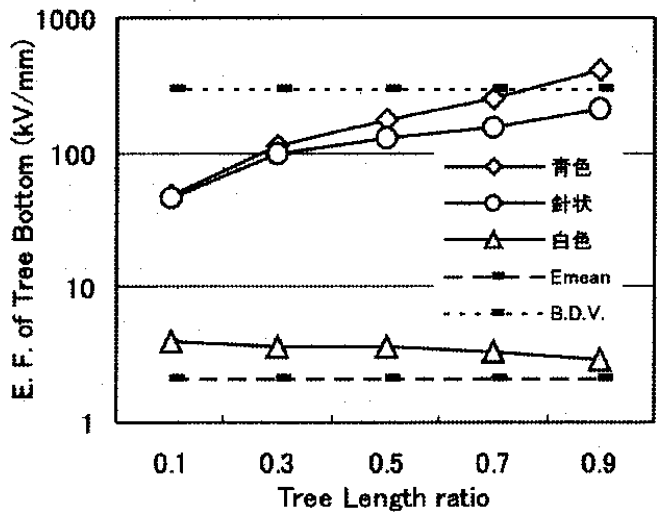

図 11 水トリ一下端電界 ( $22 \mathrm{kV}$ クス, case2)

Fig. 11. E. F. at the lower tip of water tree $(22 \mathrm{kV}$ class, case2).

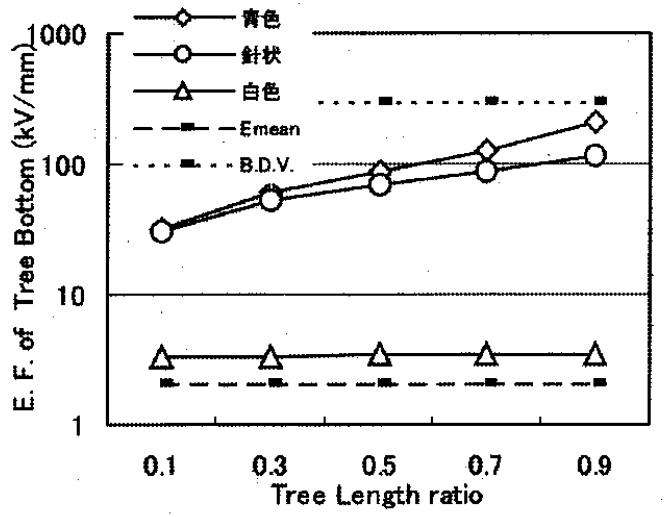

図 12 水トリー下端電界 $(22 \mathrm{kV}$ クラス, case 3 ) Fig. 12. E. F. at the lower tip of water tree $(22 \mathrm{kV}$ class, case 3 ).

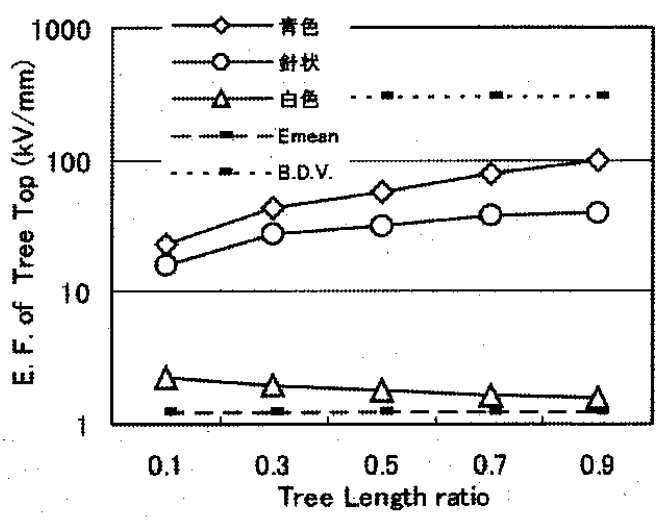

图 13 水トリ一上端電界 $(6.6 \mathrm{kV}$ クラス, case1)

Fig. 13. E. F. at the upper tip of the water tree $(6.6 \mathrm{kV}$ class, case 1$)$.

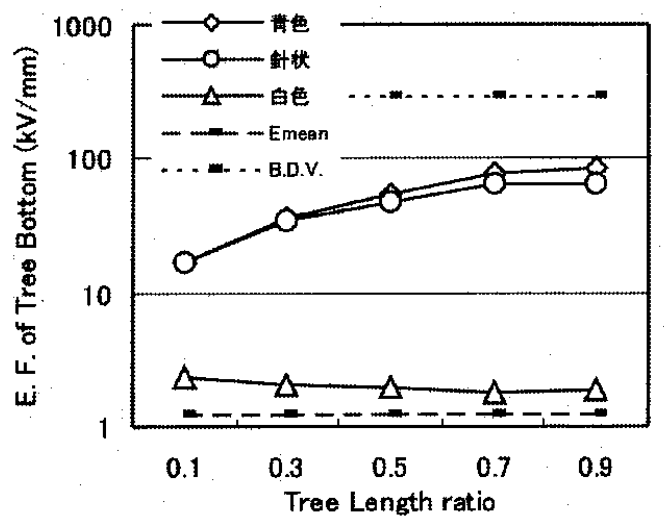

図 14 水トリー下端電界 $(6.6 \mathrm{kV}$ クラス, case2) Fig. 14. E. F. at the lower tip of water tree $(6.6 \mathrm{kV}$ class, case2).

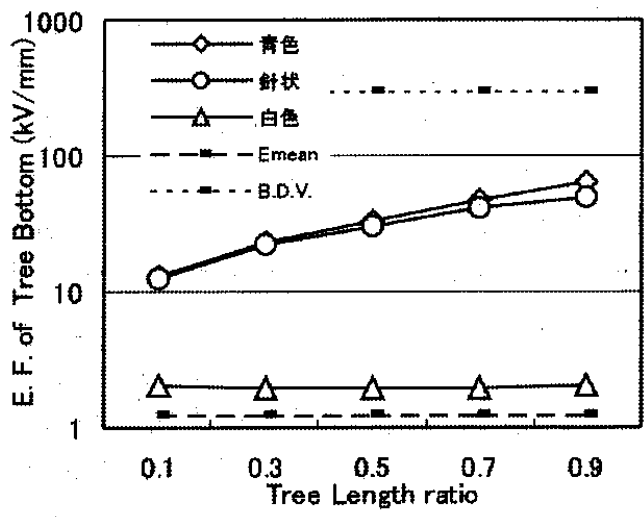

图 15 水トリ一下端電界 $(6.6 \mathrm{kV}$ クラス, case3) Fig. 15. E. F. at the lower tip of water tree $(6.6 \mathrm{kV}$ class, case3). 
を越え，絶縁破坮を起こす（図 7〜図 11 参照）。

- $6.6 \mathrm{kV}$ ケーブルでは, 先端電界が $300 \mathrm{kV} / \mathrm{mm}$ を越え ることはないが, 貫通した後, 絶縁破壊に至ると考え られる(図 13〜図 15 参照)。

針状トリー

・針状トリーは青色トリーほど進展に伴う電界上昇はな く, 青色トリーほど急激には水トリーは進展しない。

- $66 \mathrm{kV}$ ケーブルでは, 内導に近接した場合, 水トリー下 端電界が $300 \mathrm{kV} / \mathrm{mm}$ を越え絶縁破壊を起こす（図 8 参照)。

-内導に接触するまでは, 水トリー下端電界の方が上端よ り高く, 絶縁破壊は下端側で起こる (図 5 , 図 6 参照)。

- $22 \mathrm{kV}, 6.6 \mathrm{kV}$ ケーブルでは，貫通するまで進展する。 買通した後, 劣化が進むと絶縁破壊を起こすと考えら れる(図 10～図 15 参照)。

白色水トリー

- 先端電界がケーブル平均電界とさほど恋わらず, 進展 は極めてゆっくり進むと考えられる。

- $66 \mathrm{kV}, 22 \mathrm{kV}$ ケーブルでは, 水トリーが進展し, 内導 に接触すると先端電界が平均電界程度になり, 別箅所 の異物からトリーが出やすくなり, 進展が急激に衰え ると考えられる(図 7 , 図 10 参照)。

• $6.6 \mathrm{kV}$ ケーブルでは $66 \mathrm{kV}$ ケーブルほどではないが, ゆっくり進展し, 貫通するまでのびる。貫通した後, 劣化が進めば絶緣破壊が起きると考えられる（図 13 図 15 参照)。

\section{5. をとめ}

水トリー先端電界を, 3 次元の電界解析により計算した。 まず, 針状水トリーの前駆遮断試験を行い, その結果を 3 次元の有限要素法で電界解析した。水トリーの形状は簡単 のため回転棈円体で模擬し, 水トリーの位置, 長さ, 先端曲 率は顕微鏡写真から読みとった。全 11 例について解析を 行い, 導電率を $5.0 \times 10^{-7} \mathrm{~S} / \mathrm{m}$ にすると陚驗結果をうまく 説明できた。次に, 上記の針状水トリーを含む 3 種類の水 トリーについて導電率を変えることで模擬し, 水トリーの 内導からの距離を 3 種類に変化させ, また, $6.6,22,66 \mathrm{kV}$ のケープル（絶緣厚： $3,6,9 \mathrm{~mm}$ ) について, それぞれ 解析を行った。水トリーの形状は回転棈円体で模擬し, 先 端曲率は $20 \mu \mathrm{m}$ で固定した。これを, 同じく 3 次元の有 限要素法で電界解析を行い, 水トリーの先端電界を計算し た。その結果, $66 \mathrm{kV}$ ケーブルでは青色トリーと針状トリー が, $22 \mathrm{kV}$ ケーブルでは青色トリーが, 運転電圧で絶縁破 壊を起こすことが分かった。その他のトリーは貫通するま で伸びる可能性があることが分かった。貫通した後, 更に 劣化が進めば, 運転中に破壊を起こす可能性はある。また, 白色トリーは $66,22 \mathrm{kV}$ ケーブルにおいて, 内導に接触する
と先端電界が平均電界と同程度になり, 進展が急激に衰え る可能性が示唆された。

水トリーの有害性を推定する上で, これらの結果は大い に参考になると考えられる。

(平成 14 年 7 月 3 日受付, 平成 14 年 12 月 19 日再受付)

\section{文献}

(1) H. Ohno, G. Katsuta, I. Kajiki, K. Kato, Y. Sakaguchi, and G. Tanimoto: "A Study on Electrical Deterioration and Quality Control of XLPE Cable", Proc. of the 4th Annual Conference of Power and Energy Society, IEE Japan, No.44 (1993)(in Japanese)

大野·勝田・加治·加藤・坂口・谷本：「CV ケーブルの絶緣劣化と 品質に関する一考祭」, 平成 5 年電父学会電力・エネルギー部門大 会, No.44 (1993)

(2) A. Toya, K. Muraoka, S. Katakai, S. Hiwatari, and M. Kanaoka: "A Study of the harmfulness of bow-tie-tree in XLPE cable" 1994 National Convention Record, IEE Japan, No.1592 (1994) (in Japanesc) 户谷・村岡・片貝・日渡・金岡：「CV ケーブルのボウタイトリーの 有害性の検討」, 平成 6 华電気学会全国大会, No.1592 (1994)

(3) A. Toya, K. Tetsuka, T. Goto, S. Hiwatari, S. Katakai, and T. Nakagawa: "Influence of Pre-Curing on Water Tree Growth of XLPE" 1995 National Convention Record, IEE Japan, No.385 (1995) (in Japanese)

万谷・手榢・後藤・且渡・片貝・中川：「水トリー伸㬨に及ばすプレ 架橋の影粱」, 平成 7 年電気学会全国大会, No.385 (1995)

(4) T. Sakamoto and K. Mori: "Influence of Water-trees on A.C. Breakdown in XLPE Cable" 1995 National Convention Record, IEE Japan, No.1865 (1997) (in Japanese) 䛀本・森：「CV ケーフルの交流破壊に及ほす水トリーの有復性」, 平 成 9 年䉓父学会全国大会, No.1865 (1997)

（5）電気協同研究, Vol.51, No.1, p.54 (1995)

(6) T. Toyoda, S. Mukai, Y. Ohki, Y. Li, and T. Maeno: "Conductivity and Permittivity of Water Trees in Polyethylene" T. IEE japan, Vol.120-A, No.7, p.753 (2000-7) (in Japanese) 豊田・向井・大木・李・前野:「ホリエチレン中の水トリーの導電率 と誘承率」, 電学論 A, 120, 7, p.753 (2000-7)

中 出 雅 彦 (正員) 1961 年 4 月 24 日生。1987 年果京工業

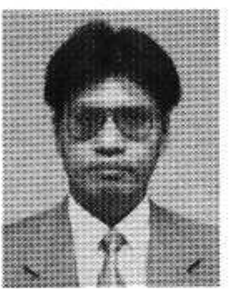
大学エネルギー科学専改修士課程修了。同年東京 電力 (株) 入社。現在技術開発研究所送変電技術 グルーブ所属。主として地中電力ケーフルの研究 開発に彷事。

井上大輔 (正員) 1970 年 8 月 18 日生。1995 年横浜国立大

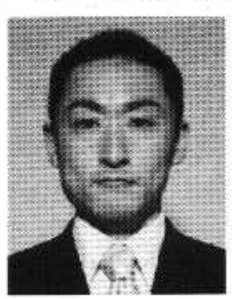
学大学院需子情報工学専攻修士課程修了。同年東 京電力 (株) 入社。現在東京支店江東支社地中送 電保守グループ所属。地中電力ケーフルル建設, 保守ならびに研究開発に従事。 